Peter H. Janssen · Bernhard Schink

\title{
Metabolic pathways and energetics of the acetone-oxidizing, sulfate-reducing bacterium, Desulfobacterium cetonicum
}

Received: 11 August 1994/ Accepted: 6 December 1994

\begin{abstract}
Acetone degradation by cell suspensions of $D e$ sulfobacterium cetonicum was $\mathrm{CO}_{2}$-dependent, indicating initiation by a carboxylation reaction. Degradation of butyrate was not $\mathrm{CO}_{2}$-dependent, and acetate accumulated at a ratio of $1 \mathrm{~mol}$ acetate per mol butyrate degraded. In cultures grown on acetone, no CoA transfer apparently occurred, and no acetate accumulated in the medium. No CoA-ligase activities were detected in cell-free crude extracts. This suggested that the carboxylation of acetone to acetoacetate, and its activation to acetoacetyl-CoA may occur without the formation of free acetoacetate. Acetoacetyl-CoA was thiolytically cleaved to two acetyl-CoA, which were oxidized to $\mathrm{CO}_{2}$ via the acetyl-CoA/carbon monoxide dehydrogenase pathway. The measured intracellular acyl-CoA ester concentrations allowed the calculation of the free energy changes involved in the conversion of acetone to acetyl-CoA. At in vivo concentrations of reactants and products, the initial steps (carboxylation and activation) must be energy-driven, either by direct coupling to ATP, or coupling to transmembrane gradients. The $\Delta G^{\prime}$ of acetone conversion to two acetyl-CoA at the expense of the energetic equivalent of one ATP was calculated to lie very close to $0 \mathrm{~kJ}$ (mol acetone $)^{-1}$. Assimilatory metabolism was by an incomplete citric acid cycle, lacking an activity oxidatively decarboxylating 2-oxoglutarate. The low specific activities of this cycle suggested its probable function in anabolic metabolism. Succinate and glyoxylate were formed from isocitrate by isocitrate lyase. Glyoxylate thus formed was condensed with acetylCoA to form malate, functioning as an anaplerotic sequence. A glyoxylate cycle thus operates in this strictly anaerobic
\end{abstract}

P. H. Janssen $(\bowtie)^{1} \cdot$ Bernhard Schink

Fakultät für Biologie, Universität Konstanz, Postfach 5560, D-78434 Konstanz, Germany

Present address:

${ }^{1}$ Max-Planck-Institut für Terrestrische Mikrobiologie, Karl-von-Frisch-Strasse, D-35043 Marburg, Germany Tel. +49-6421-287061; Fax +49-6421-161470 e-mail janssen@mailer.uni-marburg.de bacterium. Phosphoenolpyruvate (PEP) carboxykinase formed PEP from oxaloacetate. No pyruvate kinase activity was detected. PEP presumably served as a precursor for polyglucose formation and other biosyntheses.

Key words Anaerobic degradation - Acetone . Carboxylation - Energetics - Sulfate-reducing bacterium . Desulfobacterium cetonicum - Citric acid cycle . Glyoxylate cycle

Abbreviations $M V^{2+}$ Oxidized methyl viologen • PEP Phosphoenolpyruvate $\cdot P H B$ Poly- $\beta$-hydroxybutyrate

\section{Introduction}

Sulfate-reducing bacteria are able to grow on a wide range of organic compounds as sources of metabolic energy, and many species can oxidize these completely (to $\mathrm{CO}_{2}$ ), and presumably also assimilate intermediates as precursors for the monomeric and polymeric organic components of new cell material during growth. In aerobic and nitrate-reducing bacteria, intermediates of the citric acid cycle play an important role as anabolic precursors. Among the sulfatereducing bacteria, Desulfobacter postgatei and Desulfobacter hydrogenophilus oxidize acetate via a modified citric acid cycle (Brandis-Heep et al. 1983; Gebhardt et al. 1983; Schauder et al. 1987). Desulfobacter hydrogenophilus can also grow autotrophically on $\mathrm{H}_{2}$ plus $\mathrm{CO}_{2}$ and sulfate, using a reductive (reversed) citric acid cycle to assimilate $\mathrm{CO}_{2}$ and synthesize intermediates for anabolic metabolism (Schauder et al. 1987). Desulfovibrio species and Desulfobulbus propionicus have some citric acid cycle enzyme activities, postulated to be involved in assimilatory metabolism (Lewis and Miller 1975, 1977) and in catabolic propionate oxidation (Stams et al. 1984; Kremer and Hansen 1988), respectively.

Many genera of sulfate-reducing bacteria capable of complete oxidation of their growth substrates, oxidize acetyl-CoA to $\mathrm{CO}_{2}$ via the acetyl-CoA/carbon monoxide dehydrogenase pathway rather than through the citric acid cycle (Schauder et al. 1986; Thauer 1988). Except for any 
compounds that may be synthesized directly from the growth substrate or its metabolic intermediates, the majority of cellular carbon will be derived from acetyl-CoA (and $\mathrm{CO}_{2}$ ). This would necessitate at least part of a citric acid cycle in such organisms.

The anaerobic metabolism of acetone appears to involve the carboxylation of acetone to acetoacetate (or acetoacetyl-CoA), followed by thiolytic cleavage to two acetyl-CoA residues (Bonnet-Smits et al. 1988; Platen and Schink 1990; Platen et al. 1990), but the initial carboxylating activity has not been measured in vitro. In the sulfate-reducing bacterium Desulfococcus biacutus, acetyl$\mathrm{CoA}$ is further oxidized to $\mathrm{CO}_{2}$ via the acetyl-CoA/carbon monoxide dehydrogenase pathway (Platen et al. 1990).

Recently, a new strain of sulfate-reducing bacterium also able to grow on acetone was isolated and assigned to a new species, Desulfobacterium cetonicum (Galushko and Rozanova 1991). The catabolic pathways of this new organism have not been elucidated. We investigated the catabolic activities and energetics of acetone metabolism by $D$. cetonicum. In addition, other enzyme activities were detected that allow us to postulate the major assimilatory pathway and anaplerotic sequences.

\section{Materials and methods}

Organism and culture conditions

Desulfobacterium cetonicum strain 480 (Galushko and Rozanova 1991) was obtained from A. S. Galushko (Institute of Microbiology, Russian Academy of Sciences, Moscow). Stock cultures were grown in completely filled $50-\mathrm{ml} \mathrm{screw-capped} \mathrm{glass} \mathrm{bottles} \mathrm{using}$ a sulfide-reduced bicarbonate-buffered medium supplemented with a seven-vitamin mixture (Dörner and Schink 1990) with the addition of $10 \mathrm{mM}$ acetone or butyrate and $20 \mathrm{mM} \mathrm{Na}_{2} \mathrm{SO}_{4}$, and with the $\mathrm{NaCl}$ and $\mathrm{MgCl}_{2} \cdot 6 \mathrm{H}_{2} \mathrm{O}$ concentrations increased to 10 and $1.75 \mathrm{~g} \mathrm{l}^{-1}$, respectively. Larger culture volumes were grown in 250 $\mathrm{ml}$ glass bottles sealed with black rubber stoppers and containing $200 \mathrm{ml}$ of the same medium under a headspace of $\mathrm{N}_{2} / \mathrm{CO}_{2}(80: 20$; $\mathrm{v} / \mathrm{v}$ ). All cultures were incubated in the dark at $30^{\circ} \mathrm{C}$.

\section{Preparation of cell suspensions and extracts}

Cells were harvested by centrifugation under strictly anoxic conditions as described previously (Janssen and Schink 1993) and washed and resuspended in anoxic $125 \mathrm{mM}$ triethanolamine ( $\mathrm{pH}$ adjusted to 7.4 with $\mathrm{HCl}$ ) containing $2.5 \mathrm{mM}$ dithioerythritol. Cell extracts were prepared by French press treatment as described elsewhere (Janssen and Schink 1993).

Cell suspensions were prepared by centrifugation under anoxic conditions and were washed and resuspended in anoxic $50 \mathrm{mM}$ potassium phosphate buffer ( $\mathrm{pH} 7.2$ ) supplemented with $20 \mathrm{mM}$ $\mathrm{Na}_{2} \mathrm{SO}_{4}$ and $2.5 \mathrm{mM}$ dithioerythritol and containing $10.0 \mathrm{~g} \mathrm{NaCl}$ and $1.75 \mathrm{~g} \mathrm{MgCl}_{2} \cdot 6 \mathrm{H}_{2} \mathrm{O}$ per liter. Suspensions $(30 \mathrm{ml} ; 0.1$ to $0.3 \mathrm{mg}$ protein $\mathrm{ml}^{-1}$ ) were incubated at $30^{\circ} \mathrm{C}$ in sealed vials under a headspace either of $\mathrm{N}_{2} / \mathrm{CO}_{2}(80: 20 ; \mathrm{v} / \mathrm{v})$ with the addition of $30 \mathrm{mM}$ $\mathrm{NaHCO}_{3}$ to the buffer, or of $\mathrm{N}_{2}$ with the addition of $30 \mathrm{mM} \mathrm{NaCl}$ instead of $\mathrm{NaHCO}_{3}$. An appropriate substrate was then added (the cells had been grown on the same substrate), and degradation was followed by taking samples by syringe for analysis.

Acyl-CoA ester determination

Dense suspensions $(1 \mathrm{ml})$ of acetone-grown cells $(6.5$ to $7.0 \mathrm{mg}$ protein $\mathrm{ml}^{-1}$ ) were incubated in $2-\mathrm{ml}$ vials at $30^{\circ} \mathrm{C}$ in phos- phate/sulfate/dithioerythritol buffer (see above) containing $30 \mathrm{mM}$ $\mathrm{NaHCO}_{3}$ under a headspace of $\mathrm{N}_{2} / \mathrm{CO}_{2}(80: 20 ; \mathrm{v} / \mathrm{v})$. Acetone (5 $\mathrm{mM}$ ) was added, followed $60 \mathrm{~s}$ later by $500 \mathrm{kBq} \mathrm{Na}{ }^{14} \mathrm{CO}_{3}$ in $20 \mu \mathrm{l}$ $1 \mathrm{mM} \mathrm{KOH}$. Samples of $200 \mu \mathrm{l}$ were taken at intervals ( $30 \mathrm{~s}$ to 2 min) using accurate Unimetrics syringes (Macherey-Nagel, Düren, Germany) and added to $25 \mu \mathrm{I} 70 \%$ (w/v) perchloric acid. The preparations were allowed to stand for $30 \mathrm{~min}$, then centrifuged in a benchtop microcentrifuge at $5,000 \times g$, gassed with $\mathrm{CO}_{2}$ at 100 $\mathrm{ml} \mathrm{min}-1$ for $30 \mathrm{~min}$, and then centrifuged again. The acyl-CoA esters were separated by reversed-phase HPLC (Brune and Schink 1990; Gorny and Schink 1994) and quantified by comparison to standards of acyl-CoA esters also treated with perchloric acid. The acyl-CoA esters were stable under the experimental conditions used. Intracellular acyl-CoA ester concentrations remained constant, while substrate remained. Incorporation of ${ }^{14} \mathrm{CO}_{2}$ into intracellular acyl-CoA esters was followed by monitoring radioactivity on-line (Gorny and Schink 1994) using $1{ }^{14} \mathrm{C}$-benzoate as an external standard. To calculate intracellular concentrations, we used

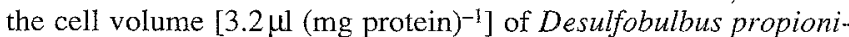
cus, as determined by Kreke and Cypionka (1992), a similarly sized sulfate-reducing bacterium (cf. Widdel and Pfennig 1982; Galushko and Rozanova 1991).

\section{Enzyme assays}

Assays were carried out at $30^{\circ} \mathrm{C}$ as described by Brune and Schink (1990) using a 100-40 photometer (Hitachi, Tokyo, Japan) in 1-ml volumes in $1.5-\mathrm{ml}$ semi-microcuvettes under $\mathrm{N}_{2}$ unless noted otherwise. Linearity with added crude extract was tested, and dependence on key additions in the test (e.g., substrate, CoA, ADP) was checked. The oxidation or reduction of electron acceptors was followed as described by Möller-Zinkhan and Thauer (1988). The reduction of $2 \mu \mathrm{mol}$ methyl viologen was defined as the oxidation of 1 umol substrate. Enzyme activities are expressed as $\mu \mathrm{mol}$ substrate transformed per $\mathrm{mg}$ cell-free crude extract protein and are means of 3-5 determinations.

Acetyl-CoA:3-hydroxybutyrate CoA transferase (EC2.8.3.-) and acetyl-CoA:acetoacetate CoA transferase (EC2.8.3.-) were assayed after Janssen and Schink (1993) using $10 \mathrm{mM}$ sodium DL-3hydroxybutyrate plus $2 \mathrm{mM} \mathrm{NAD}{ }^{+}$and $10 \mathrm{mM}$ lithium acetoacetate plus $2 \mathrm{mM}$ NADH, respectively. 3-Hydroxybutyrate CoA ligase (EC6.2.1.-) and acetoacetate CoA ligase (EC6.2.1.16) were assayed using the acetate thiokinase assay of Oberlies et al. (1980), starting the reaction with $1 \mathrm{mM}$ sodium DL-3-hydroxybutyrate and $1 \mathrm{mM}$ lithium acetoacetate, respectively, and by assay $b$ of Fukui et al. (1982) using $0.5 \mathrm{mM}$ sodium DL-3-hydroxybutyrate plus $2 \mathrm{mM}$ $\mathrm{NAD}^{+}$and $0.5 \mathrm{mM}$ lithium acetoacetate plus $0.2 \mathrm{mM}$ NADH, respectively. 3-Hydroxybutyrate dehydrogenase (EC 1.1.1.30), 3-hydroxybutyryl-CoA dehydrogenase (EC1.1.1.35/36/157), and isopropanol dehydrogenase (EC 1.1.1.80) were all tested with NADH or NADPH as described by Platen et al. (1990). 3-Enoyl-CoA hydratase (EC 42.1.17/55), omitting BSA and increasing $\mathrm{NAD}^{+}$to 2 $\mathrm{mM}$, and acetyl-CoA acetyltransferase (EC2.3.1.9) were assayed after Wofford et al. (1986). Carbon monoxide dehydrogenase (EC 1.2.99.2) was measured as described by Diekert and Thauer (1978), and formate dehydrogenase (EC 1.2.99.-) was assayed in the same way except under $\mathrm{N}_{2}$ with the addition of $10 \mathrm{mM}$ sodium formate.

Pyruvate kinase (EC2.7.1.40) was assayed as described by Bergmeyer et al. (1974), starting the assay with $5 \mathrm{mM}$ ADP. Pyruvate orthophosphate dikinase (EC2.7.9.1) and pyruvate water $k i$ nase (EC2.7.9.2) were assayed using the same method, but starting with $5 \mathrm{mM}$ AMP plus $20 \mathrm{mM}$ tetrasodium pyrophosphate and 5 $\mathrm{mM}$ AMP plus $20 \mathrm{mM} \mathrm{K \textrm {H } _ { 2 }} \mathrm{PO}_{4}$, respectively. Pyruvate synthase (EC 1.2.7.1) was measured as described by Diekert and Thauer (1978). ATP:citrate lyase (EC4.1.3.8) was assayed by the methods of Brune and Schink (1990) and Schauder et al. (1987). Assays for isocitrate lyase (EC4.1.3.1), starting the reaction with $1.2 \mathrm{mM}$ DLisocitric acid (stock solution adjusted to $\mathrm{pH} 7.0$ with $\mathrm{NaOH}$ ), and malate synthase (EC4.1.3.2) were after Dixon and Komberg (1959). 
The following enzymes were assayed as described by Brune and Schink (1990): phosphoenolpyruvate carboxylase (EC 4.1.1.31), phosphoenolpyruvate carboxykinase (EC4.1.1.32), pyruvate carboxylase (EC6.4.1.1), citrate synthase (EC4.1.3.7), isocitrate dehydrogenase (EC 1.1.1.42) with $\mathrm{NAD}^{+}$or $\mathrm{NADP}^{+}$, malate dehydrogenase (EC 1.1.1.37) with NADH or NADPH, fumarase (EC 4.2.1.2), succinate dehydrogenase $(\mathrm{EC} 1.3 .99 .1)$ with $\mathrm{K}_{3} \mathrm{Fe}(\mathrm{CN})_{6}, 2$ oxoglutarate synthase (EC 1.2.7.3), 2-oxoglutarate dehydrogenase complex (EC 1.2.4.1, etc.) with $\mathrm{NAD}^{+}$or $\mathrm{NADP}^{+}$, succinyl-CoA:acetate CoA transferase (EC2.8.3.-), succinyl-CoA:acetoacetate CoA transferase (EC2.8.3.5), and succinate CoA ligase (EC6.2.1.4/5).

Aconitase (EC4.2.1.3) was assayed with the following reaction mixture: $100 \mathrm{mM}$ Tris (pH 8.3 with $\mathrm{HCl}$ ), $10 \mathrm{mM} \mathrm{MgCl} 2,2.5 \mathrm{mM}$ dithioerythritol, $2.5 \mathrm{mM} \mathrm{NADP}^{+}, 0.5 \mathrm{U}$ isocitrate dehydrogenase, and $5 \mathrm{mM}$ trisodium citrate.

\section{Analytical procedures}

Protein was quantified by the micro-assay of Bradford (1976) using bovine serum albumin as standard. Sulfide was measured as described by Trüper and Schlegel (1964). Acetate and butyrate were measured by HPLC (Friedrich and Schink 1993). Acetone was determined colorimetrically (Platen et al. 1994). Cell densities in cultures and cell suspensions were determined as an optical density at $440 \mathrm{~nm}$ and correlated to total cellular protein and gravimetrically determined dry mass using data obtained from similarly grown 1-1 cultures.

\section{Results}

Growth on acetone

D. cetonicum grew on acetone with sulfate as terminal electron acceptor (Fig. 1a) with a doubling time of $69 \mathrm{~h}$

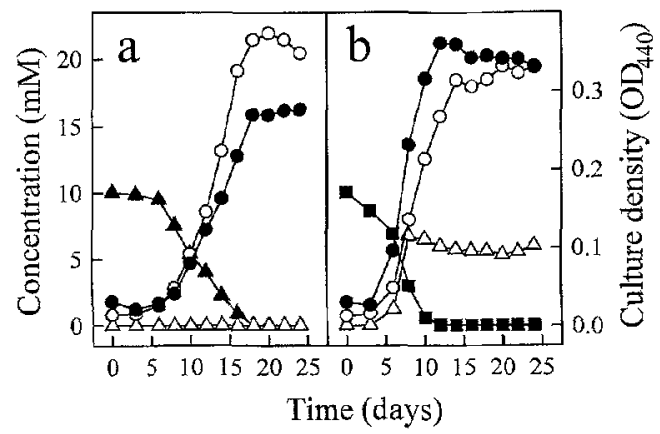

Fig. 1 Growth of Desulfobacterium cetonicum on a acetone plus sulfate and $\mathbf{b}$ butyrate plus sulfate. (Filled triangles) acetone, (filled squares) butyrate, (open triangles) acetate, (open circles) sulfide, (filled circles) culture density. An $\mathrm{OD}_{440 \mathrm{~nm}}$ of 1.00 corresponds to $120 \mathrm{mg}$ cell dry mass $1^{-1}$

Table 1 Growth yields and substrate degradation balances of Desulfobacterium cetonicum grown on acetone plus sulfate and on butyrate plus sulfate

\begin{tabular}{|c|c|c|c|c|c|c|}
\hline $\begin{array}{l}\text { Growth } \\
\text { substrate }\end{array}$ & $\begin{array}{l}\text { Substrate } \\
\text { degraded } \\
\text { ( } \mu \mathrm{mol})\end{array}$ & $\begin{array}{l}\text { Products } \\
\text { Acetate }\end{array}$ & sulfide & $\begin{array}{l}\text { Sulfide } \\
\text { recov- } \\
\text { ery }(\%)^{\mathrm{a}}\end{array}$ & $\begin{array}{l}\text { Cell } \\
\text { yield } \\
\text { (mg) }\end{array}$ & $\begin{array}{l}\mathrm{Y}_{s} \\
(\mathrm{~g} \\
\left.\mathrm{mol}^{-1}\right)\end{array}$ \\
\hline Acetor & 1,960 & 0 & 3,980 & 102 & 5.9 & 3.0 \\
\hline Butyrate & 1,680 & 1,080 & 2,880 & 92 & 7.7 & 4.6 \\
\hline
\end{tabular}

a Expressed as a percentage of theoretical sulfide production (see Eqs. 1 and 2 in text) $\left(\mu=0.240 d^{-1}\right)$. With butyrate plus sulfate (Fig. 1b), the doubling time was $39 \mathrm{~h}\left(\mu=0.432 \mathrm{~d}^{-1}\right)$. Sulfide was produced concomitantly with substrate utilization and an increase in culture density. Acetate accumulated in cultures

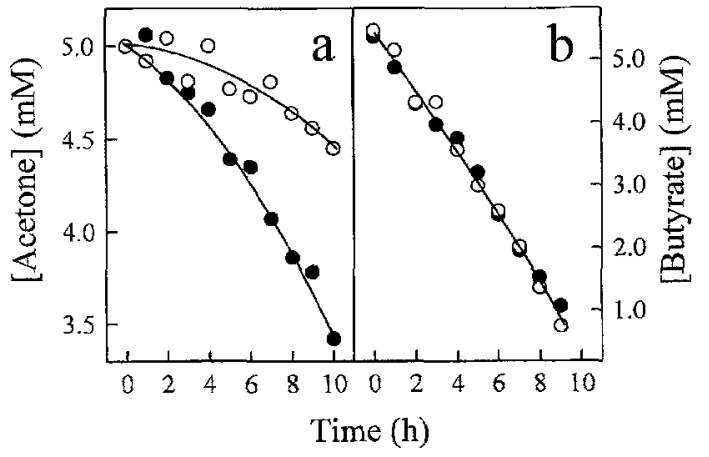

Fig. 2 Degradation of a acetone, and $\mathbf{b}$ butyrate by cell suspensions of Desulfobacterium cetonicum in the presence (filled circles) and absence (open circles) of $\mathrm{CO}_{2} / \mathrm{HCO}_{3}{ }^{-}$

Table 2 Enzyme activities in cell-free crude extracts of acetonegrown $D$. cetonicum. The numbers of the enzymes refer to Fig. 4. The following activities were not detected $\left[<1 \mathrm{nmol} \mathrm{min}{ }^{-1}(\mathrm{mg}\right.$ protein $)^{-1}$ ]: isopropanol dehydrogenase $\left(\mathrm{NAD}^{+}\right.$or $\mathrm{NADP}^{+}$), 3-hydroxybutyrate dehydrogenase $\left(\mathrm{NAD}^{+}\right.$or $\mathrm{NADP}^{+}$, acetyl-CoA: acetoacetate $\mathrm{CoA}$ transferase, 3-hydroxybutyrate CoA ligase, acetoacetate $\mathrm{CoA}$ ligase, 2-oxoglutarate synthase $\left(\mathrm{MV}^{2+}\right)$, 2-oxoglutarate dehydrogenase $\left(\mathrm{NAD}^{+}\right.$or $\mathrm{NADP}^{+}$), ATP: citrate lyase, malate dehydrogenase (NADP ${ }^{+}$), isocitrate dehydrogenase $\left(\mathrm{NAD}^{+}\right)$, pyruvate kinase, PEP carboxylase, pyruvate carboxylase, pyruvate orthophosphate dikinase, pyruvate water kinase, succinate $\mathrm{CoA}$ ligase, acetyl-CoA: 3-hydroxybutyrate CoA transferase, succinylCoA: acetate CoA transferase, succinyl-CoA: acetoacetate CoA transferase

\begin{tabular}{|c|c|}
\hline $\begin{array}{l}\text { Enzyme } \\
\text { (acceptor if appropriate) }\end{array}$ & $\begin{array}{l}\text { Specific } \\
\text { activity } \\
{\left[\text { nmol min }{ }^{-1}\right.} \\
\left.(\text { mg protein })^{-1}\right]\end{array}$ \\
\hline \multicolumn{2}{|l|}{ Catabolic enzymes } \\
\hline 1 Acetyl-CoA acetyltransferase [3-ketothiolase] & 7,746 \\
\hline 2 Formate dehydrogenase $\left(\mathrm{MV}^{2+}\right)$ & 3,189 \\
\hline 3 Carbon monoxide dehydrogenase $\left(\mathrm{MV}^{2+}\right)$ & 1,159 \\
\hline \multicolumn{2}{|l|}{ Anabolic enzymes } \\
\hline 4 PEP carboxykinase & 10 \\
\hline 5 Pyruvate synthase $\left(\mathrm{MV}^{2+}\right)$ & 143 \\
\hline 6 Citrate synthase & 20 \\
\hline 7 Aconitase & 21 \\
\hline 8 Isocitrate dehydrogenase $\left(\mathrm{NADP}^{+}\right)$ & 21 \\
\hline 9 Isocitrate lyase & 10 \\
\hline 10 Malate synthase & 37 \\
\hline 11 Succinate dehydrogenase $\left(\mathrm{Fe}(\mathrm{CN})_{6}{ }^{3-}\right)$ & 706 \\
\hline 12 Fumarase & 1,446 \\
\hline 13 Malate dehydrogenase $\left(\mathrm{NAD}^{+}\right)$ & 3,225 \\
\hline \multicolumn{2}{|l|}{ PHB-forming enzymes } \\
\hline $\begin{array}{l}1.4 \text { 3-Hydroxybutyryl-CoA dehydrogenase } \\
\left(\mathrm{NAD}^{+}\right)\end{array}$ & 9,039 \\
\hline $\begin{array}{l}15 \text { 3-Hydroxybutyryl-CoA dehydrogenase } \\
\left(\mathrm{NADP}^{+}\right)\end{array}$ & 59 \\
\hline 16 3-Enoyl-CoA hydratase [crotonase] & 45,471 \\
\hline
\end{tabular}


Fig.3 Relationship between the concentration of DL-isocitrate and isocitrate lyase activity in crude cell-free extracts of acetone-plus-sulfate-grown cells of Desulfobacterium cetonicum

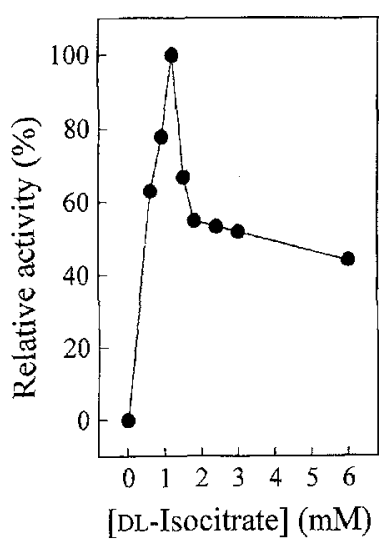

growing on butyrate at a little less than $1 \mathrm{~mol}$ per mol substrate metabolized, while cultures growing on $10 \mathrm{mM}$ acetone accumulated only traces (less than $20 \mu \mathrm{M}$ ) of acetate. The specific growth yields in batch culture were $3.0 \mathrm{~g}$ dry mass $\mathrm{mol}^{-1}$ on acetone, and $4.6 \mathrm{~g} \mathrm{~mol}^{-1}$ on butyrate (Table 1). From the specific growth rates and specific growth yields, the in vivo substrate turnover rates were calculated at $0.109 \mu \mathrm{mol} \mathrm{min}^{-1}(\mathrm{mg} \text { protein })^{-1}$ on acetone and 0.129 $\mu \mathrm{mol} \min ^{-1}$ (mg protein $)^{-1}$ on butyrate.

Acetone degradation in cell suspensions

Acetone was degraded by cell suspensions of $D$. cetonicum with an initial specific activity of $17.3 \mathrm{nmol} \mathrm{min}^{-1}$ (mg protein) $)^{-1}$ in the presence of $\mathrm{CO}_{2}$ (Fig. 2a). In the absence of added $\mathrm{CO}_{2}$, the acetone degradation rate was

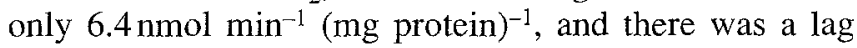
before the onset of acetone degradation. Butyrate degradation (Fig. 2b) was not dependent on the presence of $\mathrm{CO}_{2}$ [15.1 compared to $14.1 \mathrm{nmol} \mathrm{min}^{-1}$ (mg protein) ${ }^{-1}$ in the presence and absence of $\mathrm{CO}_{2}$, respectively].

Enzymology of acetone degradation

In crude cell-free extracts of acetone-plus-sulfate-grown D. cetonicum, acetyl-CoA acetyltransferase (3-ketothiolase) activity was found (Table 2 ). Formate dehydrogenase and carbon monoxide dehydrogenase activities, both measured with $\mathrm{MV}^{2+}$ as artificial acceptor, were present (Table 2). 3-Hydroxybutyryl-CoA dehydrogenase (with $\mathrm{NAD}^{+}$) and 3-enoyl-CoA hydratase (acting with crotonyl$\mathrm{COA}$ ) activities were also present.

Anabolic enzyme activities

In $D$. cetonicum, a $\mathrm{MV}^{2+}$ - and CoA-dependent pyruvate synthase was found (Table 2). No pyruvate kinase activity could be detected. PEP carboxykinase activity was present and was dependent on the presence of ADP $(11 \%$ activity in the absence of $\mathrm{ADP})$ and $\mathrm{KHCO}_{3}(7 \%$ activity in the absence of $\mathrm{KHCO}_{3}$ ). Other carboxylases acting on pyruvate or PEP were not detected (Table 2).
Table 3 Intracellular acyl-CoA ester concentrations in acetoneplus-sulfate-grown Desulfobacterium cetonicum. A cell volume of $3.2 \mu \mathrm{l}$ per mg protein (see Materials and methods) was used to calculate the intracellular concentrations

\begin{tabular}{llr}
\hline Acyl-CoA ester & nmol (mg protein $)^{-1}$ & $\mu \mathrm{M}$ \\
\hline CoASH & 0.503 & 157 \\
Acetoacetyl-CoA & 1.869 & 584 \\
Acetyl-CoA & 1.423 & 445 \\
3-Hydroxybutyryl-CoA & 8.054 & 2,517 \\
Crotonyl-CoA & 0.391 & 122 \\
\hline
\end{tabular}

Citrate synthase activity was present, but no ATP:citrate lyase (Table 2). Aconitase, isocitrate dehydrogenase (with $\mathrm{NADP}^{+}$, but not with $\mathrm{NAD}^{+}$), malate dehydrogenase (with $\mathrm{NAD}^{+}$, but not with $\mathrm{NADP}^{+}$), fumarase, and succinate dehydrogenase (using $\mathrm{Fe}(\mathrm{CN})_{6}^{3-}$ as an artificial acceptor) were detected (Table 2). Enzymes oxidatively decarboxylating 2-oxoglutarate were not found. Isocitrate lyase and malate synthase activities were present. The isocitrate lyase from $D$. cetonicum displayed maximum activity at a DL-isocitrate concentration of $1.2 \mathrm{mM}$, while higher concentrations caused a decrease in activity (Fig. $3)$.

Acyl-CoA ester concentrations in cells

Intracellular acyl-CoA and free $\mathrm{CoASH}$ concentrations were measured in acetone-metabolizing cell suspensions of acetone-grown cultures (Table 3 ). The levels were constant over the 5-min experiment. The rate of exchange of ${ }^{14} \mathrm{CO}_{2}$ into the intracellular CoA esters of acetone-metabolizing cell suspensions of $D$. cetonicum was similar to that obtained during butyrate degradation by dense cell suspensions of butyrate-grown $D$. cetonicum, and the specific labeling of the acyl-CoA esters was similar (data not shown).

\section{Discussion}

Acetone degradation

Desulfobacterium cetonicum grew on acetone and butyrate, with sulfate as terminal electron acceptor. The electron donors were catabolized in agreement with the following equations $\left[\Delta \mathrm{G}_{0}{ }^{\prime}\right.$ values calculated after Thauer et al. (1977)]:

$\mathrm{CH}_{3} \mathrm{COCH}_{3}+2 \mathrm{SO}_{4}{ }^{2-} \rightarrow 3 \mathrm{HCO}_{3}{ }^{-}+2 \mathrm{HS}^{-}+\mathrm{H}^{+}$

$\Delta \mathrm{G}_{0}{ }^{\prime}=-125.6 \mathrm{~kJ}$ reaction ${ }^{-1}$

$\mathrm{CH}_{3} \mathrm{CH}_{2} \mathrm{CH}_{2} \mathrm{COO}^{-}+1 / 2 \mathrm{SO}_{4}^{2-} \rightarrow \mathrm{CH}_{3} \mathrm{COO}^{-}+2 \mathrm{HCO}_{3}^{-}+$ $1 / 2 \mathrm{HS}^{-}+1 / 2 \mathrm{H}^{+}$

$\Delta \mathrm{G}_{0}{ }^{\prime}=-75.2 \mathrm{~kJ}$ reaction $^{-1}$

D. cetonicum displayed a lower specific growth yield and lower specific growth rate on acetone as compared to 
growth on butyrate, a substrate not requiring carboxylation. Per acetone, two acetyl-CoA are oxidized via the acetyl-CoA/carbon monoxide dehydrogenase pathway, i.e., $16[\mathrm{H}]$ will be oxidized. The $Y_{\mathrm{s}}$ on acetone was $3.0 \mathrm{~g}$ $\mathrm{mol}^{-1}$, or $375 \mathrm{mg}$ per mol electron pair. Butyrate is degraded by $\beta$-oxidation and the acetyl-CoA/carbon monoxide dehydrogenase pathway, after CoA-transfer from acetyl-CoA (see below). Thus, $12[\mathrm{H}]$ will be oxidized per butyrate. The $\mathrm{Y}_{\mathrm{s}}$ on butyrate was $4.6 \mathrm{~g} \mathrm{~mol}^{-1}$, or $767 \mathrm{mg}$ per mol electron pair. These data thus indicate an additional energetic load during growth on acetone. This is not likely to be transport, since acetone will readily cross the membrane, but could be the result of the endergonic carboxylation of acetone to acetoacetate $\left[+17.1 \mathrm{~kJ} \mathrm{~mol}^{-1}\right.$, Thauer et al. (1977)]. The requirement for energy in the form of ATP for the carboxylation of acetone by sulfatereducing bacteria has been postulated previously (Platen et al. 1990). In addition to labeling studies on whole cells of Desulfococcus biacutus (Platen et al. 1990), the requirement for $\mathrm{CO}_{2}$ during the catabolism of acetone by cell suspensions of $D$. cetonicum supports the hypothesis that a carboxylation step is involved in the catabolism of acetone by sulfate-reducing bacteria. The increasing rate of acetone degradation in the (initial) absence of $\mathrm{CO}_{2} / \mathrm{HCO}_{3}^{-}$can be explained by an autocatalysis due to $\mathrm{CO}_{2}$ production during slow acetone catabolism. It appears that carboxylation is generally the first step in anaerobic acetone degradation (Platen and Schink 1987, 1989; Bonnet-Smits et al. 1988).

In cultures growing on butyrate, acetate accumulated in the growth medium at approximately $1 \mathrm{~mol}$ acetate per mol substrate utilized. In addition, butyryl-CoA:acetate CoA transferase activity was measured in butyrate-grown cells, but no ligase activities were present (unpublished data). Butyrate is degraded to two acetyl-CoA residues by a classical $\beta$-oxidation pathway. One acetyl-CoA is used to activate a further butyrate, while the second is oxidized to $\mathrm{CO}_{2}$ via the acetyl-CoA/carbon monoxide dehydrogenase pathway (unpublished data). In acetone-grown cultures, in contrast, there was no acetate accumulation and also no $\mathrm{CoA}$ ligase activities activating either acetoacetate or 3-hydroxybutyrate. This suggests that the activation of the product of acetone carboxylation may be catalyzed by the same enzyme (complex) catalyzing the carboxylation, without the formation of a free acid intermediate. This remains, however, a hypothesis to be tested once the carboxylating activity can be measured in vitro.

The enzyme activities measured in cell-free extracts of acetone-grown cells of $D$. cetonicum showed that acetoacetyl-CoA was thiolytically cleaved to two acetyl-CoA moieties, which were then completely oxidized through the acetyl-CoA/carbon monoxide dehydrogenase pathway. These activities were also found in D. biacutus (Platen et al. 1990). The 3-hydroxybutyryl-CoA dehydrogenase, together with the measured 3-enoyl-CoA hydratase (crotonase), is presumably involved in poly- $\beta$-hydroxybutyrate (PHB) synthesis, but may be constitutively expressed. D. cetonicum is able to synthesize PHB (unpublished data).

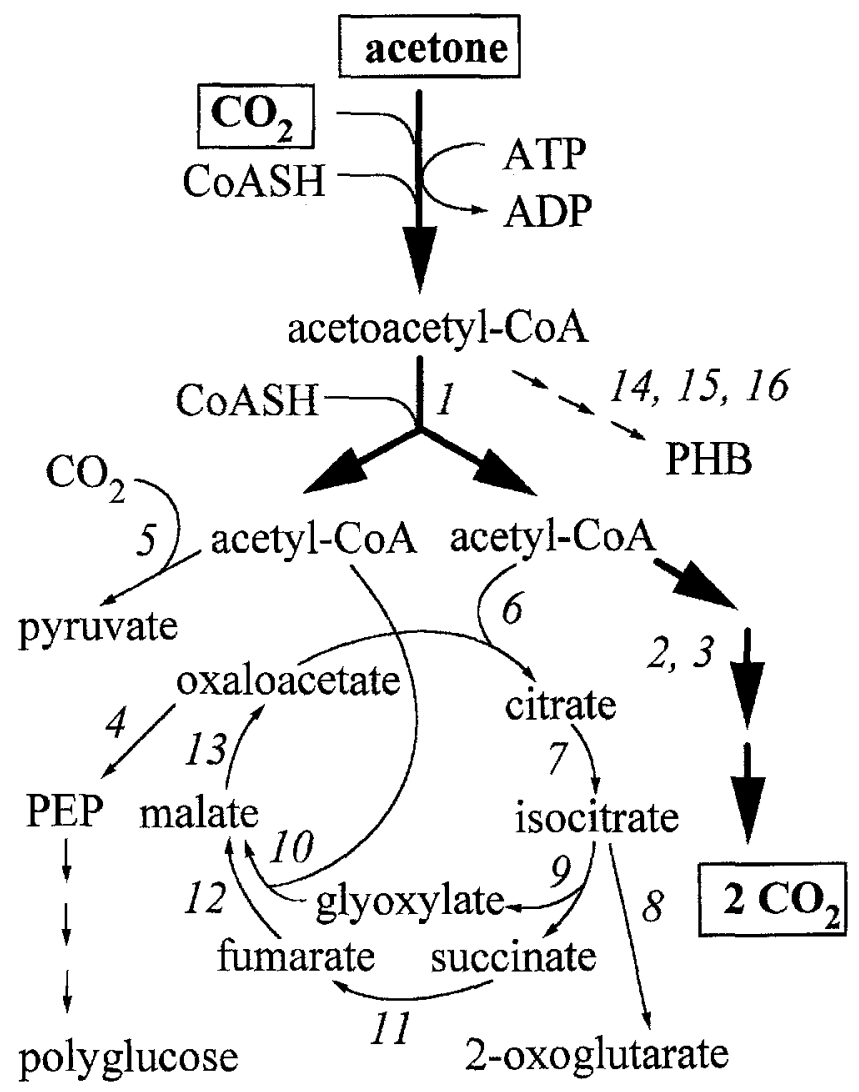

Fig. 4 Catabolic and anabolic enzyme activities detected in acetone-plus-sulfate-grown cells of Desulfobacterium cetonicum. Numbers refer to the enzyme activities listed in Table 2. Thick arrows indicate catabolic enzyme activities; thin arrows, other activities. The carboxylation of acetone and the formation of polyglucose were not measured in vitro in this study

Anabolic pathways

Cell matter in acetone-grown cultures must be synthesized from acetone, acetoacetyl-CoA, 3-hydroxybutyrylCoA, crotonyl-CoA, and acetyl-CoA. A modified citric acid cycle was present, with generally low enzyme activities. These activities probably produce the precursors for biosynthetic pathways for cell growth. Acetyl-CoA from catabolic metabolism condensed with oxaloacetate to form citrate by a citrate synthase. ATP:citrate lyase activity was not detected. Aconitase activity indicated the transformation of citrate to isocitrate. Isocitrate could be oxidatively decarboxylated to 2-oxoglutarate by an $\mathrm{NADP}^{+}$-dependent isocitrate dehydrogenase $\left(\mathrm{NAD}^{+}\right.$did not act as electron acceptor). 2-Oxoglutarate was not oxidatively decarboxylated to succinyl-CoA, either with pyridine nucleotides $\left(\mathrm{NAD}^{+}\right.$or $\mathrm{NADP}^{+}$), or with $\mathrm{MV}^{2+}$ (as a substitute for ferredoxin). No activities converting succinyl-CoA to succinate were detected. Instead, isocitrate was cleaved to succinate and glyoxylate by an isocitrate lyase activity. Succinate dehydrogenase [assayed with $\mathrm{Fe}(\mathrm{CN})_{6}{ }^{3-}$ as artificial electron acceptor], fumarase, and malate dehydrogenase with $\mathrm{NAD}^{+}$(but not $\mathrm{NADP}^{+}$) as electron acceptor, regenerated oxaloacetate for the condensation with further acetyl-CoA. 
An anaplerotic sequence was also present, in the form of malate synthase, condensing acetyl-CoA with glyoxylate formed by the activity of isocitrate lyase. The isocitrate lyase of $D$. cetonicum displayed substrate-dependent kinetics similar to the enzyme from Pseudomonas indigofera (McFadden and Howes 1961), showing pronounced inhibition at higher isocitrate concentrations. The pathway formed by the activities detected in D. cetonicum (Fig.4) allows one 4-carbon dicarboxylic acid to be assimilated into cell carbon per two acetyl-CoA entering the pathway.

In $D$. cetonicum, no pyruvate kinase activity was detected. Instead, PEP was apparently formed by the action of PEP carboxykinase acting on oxaloacetate and concomitantly utilizing ATP. Polyglucose has been detected in cells of D. cetonicum (Galushko and Rozanova 1991), but the enzyme activities of this synthetic pathway have not been determined. PEP presumably serves as a precursor for gluconeogenesis and other biosynthetic pathways.

In aerobic bacteria growing on acetate, the use of intermediates of the citric acid cycle for biosynthetic purposes will mean that oxaloacetate will no longer be stoichiometrically regenerated to act as the acetyl-CoA acceptor. Therefore, acetyl-CoA is assimilated additionally into the pool of intermediates as malate by the anaplerotic enzymes isocitrate lyase and malate synthase, forming, with the citric acid cycle, the so-called glyoxylate cycle.

The growth of $D$. cetonicum on acetone (or butyrate) similarly yields acetyl-CoA units, from which the intermediates required for biosynthetic purposes are synthesized. In this case, too, the pools of intermediates will have to be replenished to compensate for their use as precursors. This occurs through the anaplerotic glyoxylate cycle sequence of isocitrate lyase and malate synthase, and not via oxaloacetate synthesis via pyruvate and PEP. The latter is the normal anaplerotic sequence in sulfate-reducing bacteria using the citric acid cycle to oxidize acetyl-CoA (Brandis-Heep et al. 1983; Gebhardt et al. 1983, 1985; Schauder et al. 1987), and in Desulfovibrio spp. (Lewis and Miller 1977). D. cetonicum, however, uses the acetyl-CoA/carbon monoxide dehydrogenase pathway to oxidize its growth substrates. Further comparative studies are necessary to determine the correlation of the two anaplerotic sequences with the two oxidative pathways for acetyl-CoA.

\section{Energetics of acetone catabolism}

We attempted to measure the incorporation of ${ }^{14} \mathrm{CO}_{2}$ into intracellular acyl-CoA esters in dense cell suspensions metabolizing acetone. A rapid labeling of the acyl-CoA esters followed the addition of the radioactive $\mathrm{CO}_{2}$, but control experiments with butyrate produced similar results, suggesting this to be due to the rapid exchange catalyzed by enzymes of the acetyl-CoA/carbon monoxide dehydrogenase pathway, and not due to the carboxylation reaction. This is probably because the enzymes of the acetyl-CoA/carbon monoxide dehydrogenase pathway are much more active than the acetone-carboxylating enzyme. An exchange between $\mathrm{CO}_{2}$ and the carboxyl-group of acetyl-CoA has been shown to occur in a number of sulfate-reducing bacteria that oxidize acetyl-CoA via this pathway (Jansen et al. 1985; Schauder et al. 1986).

Assuming that acetone diffuses freely through the membrane and the concentrations inside and outside the cells are about equal, and using a concentration of $5 \mathrm{mM}$ for acetone, 0.2 bar for $\mathrm{CO}_{2}$, the measured concentrations of acetoacetyl-CoA, acetyl-CoA, and CoASH (Table 3 ), and a $\Delta \mathrm{G}_{0}{ }^{\prime}$ of $-35.6 \mathrm{~kJ} \mathrm{~mol}^{-1}$ for the hydrolysis of an acylCoA ester (Thauer et al. 1977), the free energy changes $\left(\Delta \mathrm{G}^{\prime}\right)$ for the combined carboxylation of acetone and subsequent activation to acetoacetyl-CoA and for the thiolytic cleavage of acetoacetyl-CoA can be calculated to be $+73.7 \mathrm{~kJ}$ reaction $^{-1}$ and $-23.2 \mathrm{~kJ}$ reaction $^{-1}$, respectively. If the hydrolysis of ATP is associated with a free energy release of $-50 \mathrm{~kJ} \mathrm{~mol}^{-1}$ (Thauer et al. 1977), then the carboxylation and activation reaction(s) resulting in acetoacetyl-CoA can be postulated to be coupled to the utilization of one ATP per acetone. The net free energy change (under in vivo conditions, $\Delta \mathrm{G}^{\prime}$ ) of acetone catabolism to two acetyl-CoA, coupled to the consumption of 1 ATP (or equivalent) would, therefore, be very close to $0 \mathrm{~kJ}$ (mol acetone) $)^{-1}$ (i.e., $+73.7 \mathrm{~kJ} \mathrm{~mol}^{-1}$ for acetone carboxylation and subsequent activation to a $\mathrm{CoA}$ ester, $-50 \mathrm{~kJ}$ $\mathrm{mol}^{-1}$ for ATP hydrolysis, and $-23.2 \mathrm{~kJ} \mathrm{~mol}^{-1}$ for the thiolytic cleavage of acetoacetyl-CoA).

The free energy change of the thiolytic cleavage of acetoacetyl-CoA is alone not sufficient to pull both the carboxylation and activation reactions. This strongly suggests that the initial reaction in the metabolism of acetone by $D$. cetonicum may be driven directly by an energy-utilizing step. Whether this coupling is directly to ATP, or via a transmembrane gradient at the expense of, for example, $3 \mathrm{H}^{+}$or $3 \mathrm{Na}^{+}$, is at present unknown.

Acknowledgements P. H. Janssen gratefully appreciates support by a fellowship from the Alexander von Humboldt-Stiftung. We thank A. S. Galushko for providing a culture of D. cetonicum.

\section{References}

Bergmeyer HU, Gawehn K, GrassI M (1974) Enzymes as biochemical reagents. In: Bergmeyer HU (ed) Methods of enzymatic analysis, vol 1, 2nd English edn. Verlag Chemie, Weinheim, pp 425-522

Bonnet-Smits EM, Robertson LA, Dijken JP van, Senior E, Kuenen JG (1988) Carbon dioxide fixation as the initial step in the metabolism of acetone by Thiosphaera pantotropha. J Gen Microbiol 134:2281-2289

Bradford MM (1976) A rapid and sensitive method for the quantitation of microgram quantities of protein utilizing the principle of protein-dye binding. Anal Biochem 72:248-254

Brandis-Heep A, Gebhardt NA, Thauer RK, Widdel F, Pfennig $\mathrm{N}$ (1983) Anaerobic acetate oxidation to $\mathrm{CO}_{2}$ by Desulfobacter postgatei. 1. Demonstration of all enzymes required for the operation of the citric acid cycle. Arch Microbiol 136:222229

Brune A, Schink B (1990) A complete citric acid cycle in assimilatory metabolism of Pelobacter acidigallici, a strictly anaerobic, fermenting bacterium. Arch Microbiol 154:394-399 
Diekert G, Thauer RK (1978) Carbon monoxide oxidation by Clostridium thermoaceticum and Clostridium formicoaceticum. J Bacteriol 136:597-606

Dixon GH, Kornberg HL (1959) Assay methods for key enzymes of the glyoxylate cycle. Biochem J 72:3P

Dörner C, Schink B (1990) Clostridium homopropionicum sp. nov. a new strict anaerobe growing with 2-, 3-, or 4-hydroxybutyrate. Arch Microbiol 154:342-348

Friedrich M, Schink B (1993) Hydrogen formation from glycolate driven by reversed electron transport in membrane vesicles of a syntrophic glycolate-oxidizing bacterium. Eur J Biochem 217: 233-240

Fukui T, Ito M, Tomita K (1982) Purification and characterization of acetoacetyl-CoA synthetase from Zoogloea ramigera I-16M. Eur J Biochem 127:423-428

Galushko AS, Rozanova EP (1991) Desulfobacterium cetonicum sp. nov.: a sulfate-reducing bacterium which oxidizes fatty acids and ketones. Mikrobiologiia (English translation) 60:742-746

Gebhardt NA, Linder D. Thauer RK (1983) Anaerobic acetate oxidation to $\mathrm{CO}_{2}$ by Desulfobacter postgatei. 2. Evidence from ${ }^{4} \mathrm{C}$-labelling for the operation of the citric acid cycle. Arch Microbiol 136:230-233

Gebhardt NA, Thauer RK, Linder D, Kaulfers PM, Pfennig N (1985) Mechanism of acetate oxidation to $\mathrm{CO}_{2}$ with elemental sulfur by Desulfuromonas acetoxidans. Arch Microbiol 141 392-398

Gorny N, Schink B (1994) Hydroquinone degradation via reductive dehydroxylation of gentisyl-CoA by a strictly anaerobic fermenting bacterium. Arch Microbiol 161:25-32

Jansen K, Fuchs G, Thauer RK (1985) Autotrophic $\mathrm{CO}_{2}$ fixation by Desulfovibrio baarsii: demonstration of enzyme activities characteristic for the acetyl-CoA pathway. FEMS Microbiol Lett 28:311-315

Janssen PH, Schink B (1993) Pathway of anaerobic poly- $\beta$-hydroxybutyrate degradation by Ilyobacter delafieldii. Biodegradation 4:179-185

Kreke B, Cypionka H (1992) Protonmotive force in freshwater sulfate-reducing bacteria, and its role in sulfate accumulation in Desulfobulbus propionicus. Arch Microbiol 158:183-187

Kremer DR, Hansen TA (1988) Pathway of propionate degradation in Desulfobulbus propionicus. FEMS Microbiol Lett 49: $273-277$

Lewis AJ, Miller JDA (1975) Keto acid metabolism in Desulfovibrio. J Gen Microbiol 90:286-292

Lewis AJ, Miller JDA (1977) The tricarboxylic acid pathway in Desulfovibrio. Can J Microbiol 23:916-921

McFadden BA, Howes WV (1961) Substrate inhibition of isocitritase. Biochim Biophys Acta 50:179-181
Möller-Zinkhan D, Thauer RK (1988) Membrane-bound NADPH dehydrogenase- and ferredoxin:NADP oxidoreductase activity involved in electron transport during acetate oxidation to $\mathrm{CO}_{2}$ in Desulfobacter postgatei. Arch Microbiol 150:145-154

Oberlies G, Fuchs G, Thauer RK (1980) Acetate thiokinase and the assimilation of acetate in Methanobacterium thermoautotrophicum. Arch Microbiol 128:248-252

Platen H, Schink B (1987) Methanogenic degradation of acetone by an enrichment culture. Arch Microbiol 149:136-141

Platen H, Schink B (1989) Anaerobic degradation of acetone and higher ketones via carboxylation by newly isolated denitrifying bacteria. J Gen Microbiol 135:883-891

Platen H, Schink B (1990) Enzymes involved in anaerobic degradation of acetone by a denitrifying bacterium. Biodegradation $1: 243-251$

Platen H, Temmes A, Schink B (1990) Anaerobic degradation of acetone by Desulfococcus biacutus spec. nov. Arch Microbiol $154: 355-361$

Platen H, Janssen PH, Schink B (1994) Fermentative degradation of acetone by an enrichment culture in membrane-separated culture devices and in cell suspensions. FEMS Microbiol Lett 122:27-32

Schauder R, Eikmanns B, Thauer RK, Widdel F, Fuchs G (1986) Acetate oxidation to $\mathrm{CO}_{2}$ in anaerobic bacteria via a novel pathway not involving reactions of the citric acid cycle. Arch Microbiol 145:162-172

Schauder R, Widdel F, Fuchs G (1987) Carbon assimilation pathways in sulfate reducing bacteria. 2. Enzymes of a reductive citric acid cycle in the autotrophic Desulfobacter hydrogenophilus. Arch Microbiol 148:218-225

Stams AJM, Kremer DR, Nicolay K, Weenk GH, Hansen TA (1984) Pathway of propionate formation in Desulfobulbus propionicus. Arch Microbiol 139:167-173

Thauer RK (1988) Citric-acid cycle, 50 years on. Modifications and an alternative pathway in anaerobic bacteria. Eur $\mathbf{J}$ Biochem 176:497-508

Thauer RK, Jungermann K, Decker K (1977) Energy conservation in chemotrophic anaerobic bacteria. Bacteriol Rev 41:100-180

Trüper HG, Schlegel HG (1964) Sulphur metabolism in Thiorhodaceae. 1. Quantitative measurements on growing cells of Chromatium okenii. Antonie Van Leeuwenhoek 30:225-238

Widdel F, Pfennig N (1982) Studies on dissimilatory sulfate-reducing bacteria that decompose fatty acids. 2. Incomplete oxidation of propionate by Desulfobulbus propionicus gen. nov., sp. nov. Arch Microbiol 131:360-365

Wofford NQ, Beaty PS, McInerney MJ (1986) Preparation of cellfree extracts and the enzymes involved in fatty acid metabolism in Syntrophomonas wolfei. J Bacteriol 167:179-185 